REVISTA DE DERECHO UNED, núm. 6, 2010

\title{
EL PATRIMONIO PROTEGIDO DE LAS PERSONAS CON DISCAPACIDAD EN EL ORDENAMIENTO JURÍDICO ESPAÑOL*
}

\author{
M. ${ }^{a}$ Fernanda Moretón SAnZ \\ Profa. Contratada Dra. Departamento de $\mathrm{D}^{\circ}$ Civil UNED. \\ Secretaria IDADFE (Instituto de Desarrollo \\ y Análisis del Derecho de Familia en España)
}

Resumen: El objeto de estas líneas será el estudio del patrimonio especialmente protegido creado por la Ley 41/2003, de 18 de noviembre, de Protección Patrimonial de las personas con discapacidad y de modificación del Código Civil, de la Ley de Enjuiciamiento Civil y de la Normativa tributaria con esta finalidad, en el marco de las políticas de protección de las personas en situaciones de discapacidad y dependencia. En particular, aquella institución de nuevo corte, se asocia al de una masa patrimonial vinculada a los intereses vitales del beneficiario.Carece por definición legal, de personalidad jurídica y responde adecuadamente a la noción tradicional de patrimonio de destino. Después una larga tramitación la mencionada Ley 41/2003 ha sido reformada por la Ley 1/2009, de 25 de marzo, de Reforma de la Ley de 8 de junio de 1957, sobre el Registro Civil, en materia de incapacitaciones, cargos tutelares y administradores de patrimonios

\footnotetext{
* Este trabajo es uno de los resultados del Proyecto de Investigación I+D+I del IMSERSO número 15/2008 que lleva por título: Residencias y alojamientos alternativos para personas mayores en situación de dependencia: Aspectos legales de la gestión, coordinación y acreditación en el SAAD de los servicios residenciales. Relevancia de los centros estatales de referencia y de la responsabilidad corporativa en la política social (Orden TAS/789/2008), siendo Investigador Principal el Profesor Carlos LASARTE ÁLVAREZ, mi Maestro, Catedrático de Derecho Civil de la UNED y Coordinadora la autora de estas líneas. En cuanto a la traducción al italiano que se publicará próximamente por la editorial Cedam, está realizada por Valentina Ruta y la revisión y adaptación jurídica a cargo del Prof. Dr. D. Fernando Val Garijo.
} 
protegidos, y de la Ley 41/2003, de 18 de noviembre, sobre protección patrimonial de las personas con discapacidad y de modificación del Código Civil, de la Ley de Enjuiciamiento Civil de la normativa tributaria con esta finalidad. Es el objeto de esta Ley «facilitar la efectiva puesta en práctica de la figura del patrimonio protegido con mecanismo de protección de las personas con discapacidad (...), la mejora de la comunicación de la constitución del patrimonio protegido al Ministerio Fiscal». Adicionalmente en este trabajo se tendrá en cuenta la Convención sobre los Derechos de las personas con discapacidad, suscrita en Nueva York el 13 de diciembre de 2006, y que forma parte del ordenamiento jurídico español habiéndose autorizado su ratificación por Ley Orgánica 1/2008, de 30 de julio. La propia Ley $1 / 2009$, marca los pasos de las futuras reformas de nuestro ordenamiento referidas, en especial a la legislación reguladora de los procedimientos de modificación de la capacidad de obrar.

Palabras claves: Personas con discapacidad. Patrimonio Protegido. Capacidad jurídica y capacidad de obrar. Registro Civil. Políticas legislativas.

Abstract: The purpose of this paper is the study of the specially patrimonio protegido created by the Ley 41/2003, de 18 de noviembre, de Protección Patrimonial de las personas con discapacidad y de modificación del Código Civil, de la Ley de Enjuiciamiento Civil y de la Normativa tributaria con esta finalidad, in the framework of the public politics of protection of disable and dependent people. In particular, this figure links a patrimonial mass to the vital interests of the beneficiary. The Law stablishes that it lacks of juridical personality, and it answers the traditional notion of the wealth or patrimonial mass with a concrete or specific destination. After a long parliament discussion, the Ley 41/2003 has been modified by the Ley $1 / 2009$, de 25 de marzo, de Reforma de la Ley de 8 de junio de 1957, sobre el Registro Civil, en materia de incapacitaciones, cargos tutelares y administradores de patrimonios protegidos, y de la Ley 41/2003, de 18 de noviembre, sobre protección patrimonial de las personas con discapacidad y de modificación del Código Civil, de la Ley de Enjuiciamiento Civil de la normativa tributaria con esta finalidad. The aim of this Law is to «facilitate the effective practice of the patrimonio protegido figure as a mechanism of protection of the persons with disabilities (...), improve the communication of the constitution of the patrimonio protegido and the Departament of Public Prosecution.» Furthermore, in this work it will be mention the Convention on the Rights of Persons with Disabilities, New York, 13 December 2006, that is part of the Spanish legal system after its ratification by the Ley 
EL PATRIMONIO PROTEGIDO DE LAS PERSONAS CON DISCAPACIDAD...

Orgánica 1/2008, de 30 de julio. The Ley 1/2009, stablishes the steps of the reforms in our system specially referred at the legislation that regulates the procedures of capacity modification.

Key words: Persons with disabilities. Protected Wealth. Legal capacity. Registry Office. Legislative policies.

Sumario: 1. Consideraciones previas sobre las políticas públicas legislativas del Estado español: De la protección de las personas con discapacidad a la construcción de un nuevo derecho subjetivo de ciudadanía sobre la autonomía personal y atención a la dependencia.-2. El patrimonio protegido como patrimonio de destino y su finalidad.-3. Beneficiarios del patrimonio especialmente protegido: el necesario reconocimiento administrativo del grado de discapacidad y el papel de la incapacitación judicial.-4. Los sujetos constituyentes y aportantes: bienes y derechos susceptibles de formar parte de la masa patrimonial.-4.1. Tipos y clases de sujetos constituyentes.-4.2. Aportaciones al patrimonio protegido: condiciones y título de la dotación.-5. Régimen de administración y supervisión del patrimonio protegido.-5.1. El sistema de administración voluntaria y convencional: la exclusión de la subasta pública.-5.2. El ámbito de la supervisión: el reforzamiento del papel del Ministerio Fiscal según la Ley 1/2009.-6. El contenido mínimo del documento constitutivo: la publicidad registral.-6.1. Documento constitutivo y formalidades imperativas.-6.2. El Registro civil y la reforma de la Ley 1/2009.-7. La extinción del patrimonio protegido: destino de los bienes y derechos aportados.-7.1. Causas de extinción: legales y convencionales.-7.2. Destino de los bienes en caso de extinción: relevancia de la autonomía de la voluntad privada.-7.3. Notas sobre la fiscalidad del patrimonio protegido y el recurso de inconstitucionalidad aún irresuelto.-8. Reflexiones finales sobre las políticas públicas nacionales: la positiva mejora de la Ley 41/2003 por la Ley 1/2009 y la incidencia en el Derecho civil de la Ley 39/2006.

1. CONSIDERACIONES PREVIAS SOBRE LAS POLÍTICAS PÚBLICAS LEGISLATIVAS DEL ESTADO ESPAÑOL: DE LA PROTECCIÓN DE LAS PERSONAS CON DISCAPACIDAD A LA CONSTRUCCIÓN DE UN NUEVO DERECHO SUBJETIVO DE CIUDADANÍA SOBRE LA AUTONOMÍA PERSONAL Y ATENCIÓN A LA DEPENDENCIA

De entre las normas que el legislador estatal español aprobó con ocasión del «Año Europeo de las Personas con Discapacidad», 
destacó, en particular, la Ley 41/2003, de 18 de noviembre, de Protección Patrimonial de las personas con discapacidad y de modificación del Código Civil, de la Ley de Enjuiciamiento Civil y de la Normativa tributaria con esta finalidad, que ha otorgado carta de naturaleza al patrimonio especialmente protegido. Además de tipificar la autotutela ${ }^{1}$ y alterar el sistema de legítimas, la Ley dota de estatuto jurídico a esta masa patrimonial sin personalidad, destinada a la satisfacción de las necesidades presentes y futuras de sus beneficiarios $^{2}$. En este punto, conviene tener presente que quien pretenda gozar de sus beneficios tendrá que acreditar un grado de discapacidad psíquica reconocida del 33 por ciento, porcentaje que asciende al 65 por ciento para las personas físicas con discapacidades físicas o sensoriales; también amparará la Ley a quienes hayan sido incapacitados por sentencia judicial firme siempre y cuando ostenten la acreditación administrativa de los mencionados tipos y grados de discapacidad.

Por otra parte, en aquella $7^{\text {a }}$ Legislatura 2000-2004 - a cargo del Partido Popular - fue aprobada la Ley 51/2003, de 2 de diciembre, de igualdad de oportunidades, no discriminación y accesibilidad universal de las personas con discapacidad, modifica a su vez, la Ley de Propiedad Horizontal. Los aspectos afectados se refieren a las obligaciones de los comuneros y al régimen de mayorías requerido para la adopción de ciertos acuerdos. Así, la accesibilidad universal se traduce para estas comunidades de vecinos en régimen de propiedad horizontal, en la preceptiva asunción de las obras cuyo importe no exceda de tres mensualidades y en la obligatoriedad de realización de las adaptaciones arquitectónicas necesarias para un uso adecuado a las personas con discapacidad. Este último aspecto puede significar que si se aprueba su ejecución, aunque el coste supere el límite antes

1 Vid., sobre la autotutela y los poderes preventivos, LEONSEGUI GUILLOT, «La autotutela como mecanismo de autoprotección de las personas mayores», La protección de las personas mayores, LASARTE ÁLVAREZ, (Dir.), Madrid, 2007, pp. 147 y ss., y «Cuestiones prácticas que plantea la autotutela tras su regulación en el Código civil por la Ley 41/2003, de 18 de noviembre», Familia, matrimonio y divorcio en los albores del Siglo XXI, Madrid, 2005, pp. 209 y ss. Sobre la publicidad de los poderes preventivos y de la designación preventiva de tutor, vid., MORETÓN SANZ, «El sistema registral de la tutela preventiva», RDUNED, 2, 2007, pp. 455 y se.

2 En este sentido, téngase en cuenta que en el caso italiano, las reformas del año 2004 conducentes a la aprobación del sistema de "amministrazione di sostengo», han creado una institución que deroga el sistema de interdicción e inhabilitación, que concentra todo el poder decisorio en manos del juez (vid., ZAMBRANO, «Dell'amministrazione di sostegno", en ZAMBRANO y AUTORINO STANZIONE, Amministrazione di sostegno. Commento alla legge 9 gennaio 2004, n. 6, 2004, pp. 128 y ss.). 
señalado, su importe total sea distribuido, sea cual sea, entre todos sus miembros en proporción a sus cuotas. En todo caso, la modificación de la Ley de Propiedad Horizontal incorpora expresamente como beneficiarios finales de las obras a personas con discapacidad o mayores de setenta años.

En cuanto a la Legislatura inmediatamente posterior $-8^{\mathrm{a}}$ años 2004 a 2008, dirigida por el Partido Socialista Español- se asientan las bases del denominado "cuarto pilar» del Estado social, circunstancia abordada por Ley 39/2006, de 14 de diciembre, de Promoción de la Autonomía Personal y Atención a las personas en situación de dependencia, relativa a la construcción de un derecho subjetivo de ciudadanía ${ }^{3}$. En este sentido, conviene destacar, que la titularidad de dicho derecho subjetivo de ciudadanía así como del conjunto de facultades, servicios y prestaciones que de él se deducen, no reside ni en la mera circunstancia cronológica, ni en la potencial resolución judicial de incapacitación que pueda ostentar un sujeto, ni siquiera la cer-

\footnotetext{
3 La autora de estas líneas ha publicado distintos trabajos sobre la materia, así vid., MORETÓN SANZ, «Derechos y obligaciones de los mayores en la nueva Ley de Promoción de la Autonomía Personal y Atención a las Personas en situación de dependencia», RMTAS, 70, 2007, pp. 45 a 70; «Los derechos de las personas con discapacidad en el ámbito europeo e internacional (Novedades jurídicas en materia de no discriminación por razón de edad, discapacidad o dependencia)», Revista de Derecho de familia de Costa Rica, 2007, pp. 15 a 27; "Protección civil de las personas con discapacidad: patrimonio especialmente protegido y accesibilidad universal en la Propiedad Horizontal», $R C D I$, 687, 2005, pp. 61 a 115. Capítulos en libros: «Los menores ante la Ley 39/2006 de autonomía personal y dependencia», Capacidad de obrar del menor: Nuevas perspectivas jurídicas, Madrid, 2009, pp. 105 a 116; «Infancia y adolescencia: la promoción de la autonomía personal y protección de menores de edad en situación de dependencia», Los menores con discapacidad en España, Madrid, 2008, pp. 439 a 520; «La construcción de un derecho subjetivo de ciudadanía: nuevas perspectivas sobre autonomía personal y dependencia», Dimensiones de la Autonomía Personal, Madrid, 2008, pp. 33 a 65; «El ejercicio de los derechos de ciudadanía y de la personalidad por los menores de edad: análisis particular del reconocimiento de la situación de dependencia en España», Actas del III Congreso Mundial sobre Derechos de la niñez y de la adolescencia», Barcelona «El nuevo sistema de protección de la persona con autonomía limitada: de la incapacitación judicial a la discapacidad y dependencia», LASARTE ÁLVAREZ (Dir.), La protección de las personas mayores, Madrid, 2007, pp. 31 a 49; "Algunas reflexiones en torno a la anunciada Ley de autonomía personal y protección de las personas con dependencia», LASARTE ÁLVAREZ (Dir.), Familia, matrimonio y divorcio en los albores del Siglo XXI, Madrid, 2006, pp. 195 a 201; «Menores necesitados de cuidados de larga duración: notas sobre el futuro sistema nacional de atención a la discapacidad y dependencia», VILLAGRASA ALCAIDE y RAVETLLAT BALLESTÉ (Coords.), Los derechos de la infancia y de la adolescencia, Barcelona, 2006, pp. 65 a 76.
} 
tificación administrativa de discapacidad ${ }^{4}$. Antes bien, la titularidad corresponde, por imperativo legal, a la ostentación de la dependencia debidamente acreditada mediante la tramitación y resolución del oportuno procedimiento donde serán de aplicación los baremos vigentes ${ }^{5}$.

Por último y después una larga tramitación cuyo iter parlamentario ha transitado por dos legislaturas (la $8^{\mathrm{a}}$ y $9^{\mathrm{a}}$ vigente), el Proyecto de reforma de la Ley del Registro Civil y de la mencionada Ley 41/2003 ha sido, finalmente, aprobado y publicado. Se trata de la Ley 1/2009, de 25 de marzo, de Reforma de la Ley de 8 de junio de 1957, sobre el Registro Civil, en materia de incapacitaciones, cargos tutelares y administradores de patrimonios protegidos, y de la Ley 41/2003, de 18 de noviembre, sobre protección patrimonial de las personas con discapacidad y de modificación del Código Civil, de la Ley de Enjuiciamiento Civil de la normativa tributaria con esta finalidad. Y su reconocido objeto es «facilitar la efectiva puesta en práctica de la figura del patrimonio protegido con mecanismo de protección de las personas con discapacidad (...), la mejora de la comunicación de la constitución del patrimonio protegido al Ministerio Fiscal» ${ }^{6}$.

4 Téngase en cuenta el sistema de homologaciones y «pasarelas» previstos en la Resolución de 23 de mayor de 2007, del Instituto de Mayores y Servicios Sociales, por la que se publica el acuerdo del Consejo Territorial del Sistema para la Autonomía y Atención a la Dependencia, por el que se establecen los acuerdos en materia de valoración de la situación de dependencia (BOE 7 de junio de 2007). Su punto segundo establece que «quienes tengan reconocida la pensión de gran invalidez, tendrán reconocido el requisito de encontrarse en situación de dependencia, con el grado y nivel que se determine mediante la aplicación del IVD (Instrumento de Valoración de Dependencia), garantizando en todo caso el Grado I Dependencia moderada, nivel I». De modo que la ostentación de una discapacidad se equipara en ciertos casos a la dependencia [por su parte, para el análisis de la discapacidad y su incidencia jurídico-civil, vid., MORETÓN SANZ, «Protección civil de la discapacidad: patrimonio protegido y obras de accesibilidad en la Propiedad horizontal», $R C D I, 2005$, 687, pp. 61 a 115 y sobre la autonomía como elemento común de distintas instituciones, de la misma autora «El nuevo sistema de protección de la persona con autonomía limitada: de la incapacitación judicial a la discapacidad y dependencia», La protección de las personas mayores, LASARTE ÁLVAREZ (Dir.), Madrid, 2007, pp. 31 a 49; De la minusvalía a la discapacidad y dependencia: pasarelas y asimilaciones legales», RUCT, 2009].

5 Real Decreto 504/2007, de 20 de abril, por el que se aprueba el baremo de valoración de la situación de dependencia establecido por la Ley 36/2006, de 14 de diciembre, de Promoción de la Autonomía Personal y Atención a las personas en situación de dependencia. También conviene analizar las observaciones hechas por el Consejo de Estado en el Dictamen sobre este Baremo (626/2007, de 12 de abril) muy especialmente las referidas al insuficiente estudio y análisis del impacto de género recogido en el informe remitido con el proyecto.

6 Preámbulo de la Ley, vid., también los interesantes debates parlamentarios que por cuestiones de espacio no se pueden transcribir, para lo que nos remitimos a 


\section{EL PATRIMONIO PROTEGIDO COMO PATRIMONIO DE DESTINO Y SU FINALIDAD}

En líneas generales y por lo que se refiere a las mencionadas políticas estatales españolas de la $7^{\mathrm{a}}$ Legislatura (años 2000-2004), cabe destacar que la preocupación por las personas con discapacidad se tradujo en la creación de un mecanismo jurídico de aplicación y corte típicamente liberales. En particular, en la institución que nace con la Ley 41/2003, de 18 de noviembre, el papel asumido por el Estado se circunscribe a autorizar su constitución a aquellas personas que cuenten con patrimonio suficiente para hacerlo, a favorecer su creación mediante la incentivación fiscal y a su tutela mediante las instituciones correspondientes. Se trata de un conjunto de medidas de carácter jurídico-privado, en las que el poder público adopta una posición vigilante o de control.

La regulación jurídica de este patrimonio protegido, era el principal objeto de la Ley 41/2003, de 18 de noviembre, intitulada oficialmente «de protección patrimonial de las personas con discapacidad y de modificación del Código Civil, de la Ley de Enjuiciamiento Civil, y de la Normativa tributaria con esta finalidad» ${ }^{7}$. En esta oca-

http://www.congreso.es/portal/page/portal/Congreso/Congreso/Iniciativas/ IniTipo?_piref73_1335527_73_1335526_1335526.next_page=/wc/detalleDocumento\&id Iniciativa $=121 \&$ numExpediente $=5 \&$ numDocumento $=0$ \&paginaActualB $=$ null

7 Vid., VIVAS TESÓN, La protección económica de la discapacidad, Barcelona, 2009; SERRANO GARCÍA, Protección patrimonial de las personas con discapacidad. Tratamiento sistemático de la Ley 41/2003, Madrid, 2008; entre otras aportaciones en la obra colectiva sobre la Protección jurídica patrimonial de las personas con discapacidad, PÉREZ DE VARGAS MUÑOZ (Coord.), vid., GALLEGO DOMÍNGUEZ, «Aproximación al patrimonio protegido del discapacitado», Madrid, 2007, pp. 113 a 180; PEREÑA VICENTE, Asistencia y protección de las personas incapaces o con discapacidad: las soluciones del Derecho civil, Universidad Rey Juan Carlos, Madrid, 2007 y Asistencia y protección de las personas incapaces o con discapacidad, Dykinson, Madrid, 2006; RIVERA ÁLVAREZ, "La capacidad de obrar suficiente en el patrimonio protegido de las personas con discapacidad», $R D P$, 2006; DÍAZ ALABART y ÁLVAREZ MORENO, La protección jurídica de las personas con discapacidad, Madrid, 2004; LUCINI NICÁS, «La Ley 41/2003, de protección patrimonial de las personas con discapacidad y de modificación del Código civil, de la Ley de Enjuiciamiento Civil y de la Normativa Tributaria», AC, 14, julio, 2004, pp. 1.621 a 1.653; MARTÍN SANTIESTEBAN, «El patrimonio de destino de la Ley de protección patrimonial de las personas con discapacidad: ¿un acercamiento al trust?, Actualidad Jurídica Aranzadi, 612, 2004; PÉREZ JIMÉNEZ, "Algunas reflexiones en torno a la Ley 41/2003, de 18 de noviembre, de Protección Patrimonial de las personas con discapacidad», AC, 21, 2004, pp. 2.540 a 2.558; PEREÑA VICENTE, «El incapacitado ante la nueva protección jurídica del discapacitado», $A C$, 15, septiembre, 2004; RIVERA ÁLVAREZ, "Una perspectiva civil de las últimas reformas planteadas en materia de discapacidad», Revista del Ministerio de Trabajo y Asuntos Sociales, 50, 2004, pp. 91 a 119; SÁNCHEZ RE- 
sión, como se ha avanzado, el legislador se centró en los aspectos puramente materiales de la discapacidad, con la aspiración de que la asistencia económica a la persona se hiciese con cargo a su propio patrimonio. Por tanto, su finalidad última era garantizar la asistencia y atención especializada presente y futura que requieran, incluso, cuando sobrevivan a sus progenitores. Es decir, son medidas que tienden a afectar ciertos medios económicos de iniciativa privada a la satisfacción de las necesidades de estas personas con discapacidad y por extensión, a su familia.

De cuanto antecede se puede concluir que la noción de este patrimonio especialmente protegido se asocia al de una masa patrimonial vinculada a los intereses vitales del beneficiario. Carece por definición legal, de personalidad jurídica y responde adecuadamente a la noción tradicional de patrimonio de destino ${ }^{8}$. La falta de previsión legal sobre las deudas y obligaciones que, en su caso, genere esta masa patrimonial, y la ausencia de un régimen especial que singularice su responsabilidad sobre el patrimonio ordinario del beneficiario y titular, impiden la calificación del conjunto como unidad patrimonial separada ${ }^{9}$. No hay por tanto, separación de patrimonios ante la mencionada ausencia de caracterización legal; la masa patrimonial ni se singulariza del resto de los bienes, ni está aislada del patrimonio general ordinario del titular y beneficiario sino por su finalidad y supervisión ${ }^{10}$.

YERO, «El discapacitado ante el Derecho Civil y Fiscal contemporáneo», Información jurídica, 49, junio, 2004, pp. 1 a 7; ZURITA MARTÍN, Protección civil de la ancianidad, Madrid, 2004; BERCOVITZ RODRÍGUEZ-CANO, "La protección patrimonial de las personas con discapacidad», Aranzadi Civil, 16, 2003; CARRASCO PERERA, «Acoso y derribo de la legítima hereditaria», Actualidad Jurídica Aranzadi, 580, 2003; VARGAS CABRERA, "Aspectos civiles y procesales de la discapacidad», La protección jurídica del discapacitado, SERRANO GARCÍA (Coord. y Dir.), Valencia, 2003; MUÑOZ DE DIOS, «El patrimonio del discapacitado», MARTÍNEZ DÍE (Dir.), La protección jurídica de discapacitados, incapaces y personas en situaciones especiales, Madrid, 2000; GONZÁLEZ POVEDA (Coord.), Los Discapacitados y su protección jurídica, Estudios de Derecho Judicial, 22, Madrid, 1999; LEÑA FERNÁNDEZ, El notario y la protección del discapacitado, Madrid, 1997.

8 Como las colectas u cuestaciones públicas organizadas para conseguir fondos sin personalidad jurídica propia (vid., LASARTE ÁlVAREZ, Principios de Derecho Civil, 1, Parte General y Derecho de la persona, Madrid, 2008, 14ª ed., pp. 357 y s.).

9 Los términos de la Exposición de Motivos son los siguientes: «los bienes y derechos que forman este patrimonio, que no tiene personalidad jurídica propia, se aíslan del resto del patrimonio personal de su titular-beneficiario, sometiéndolos a un régimen de administración y supervisión específico. Se trata de un patrimonio de destino, en cuanto que las distintas aportaciones tienen como finalidad la satisfacción de las necesidades vitales de sus titulares».

${ }_{10} \mathrm{Si}$ bien el fundamento y especialidades del patrimonio separado son discutidos, uno de los argumentos que sustenta su configuración legal se basa en la se- 
Refuerza esta idea el tratamiento fiscal del patrimonio protegido. La persona con discapacidad titular y beneficiaria de este patrimonio, tributará por lo que a las aportaciones realizadas se refiere, como rendimiento íntegro del trabajo en el IRPF y en lo que exceda, por el Impuesto sobre Sucesiones y Donaciones ${ }^{11}$. En definitiva, el patrimonio protegido incluso a efectos tributarios no es más que una masa de bienes y derechos de los que es titular el sujeto beneficiario, que si se aíslan del patrimonio ordinario, no es sino por las especialidades de administración y supervisión que luego se dirán.

\section{BENEFICIARIOS DEL PATRIMONIO ESPECIALMENTE PROTEGIDO: EL NECESARIO RECONOCIMIENTO ADMINISTRATIVO DEL GRADO DE DISCAPACIDAD Y EL PAPEL DE LA INCAPACITACIÓN JUDICIAL}

El beneficiario de esta norma se determina por criterios reglamentarios indirectos ${ }^{12} \mathrm{o}$, en su caso, por resolución judicial firme. Así, podrán ser titulares y beneficiarios: a) Personas con una discapacidad psíquica reconocida del 33 por ciento o más, estén o no incapacitadas judicialmente; b) personas con discapacidades acreditadas de carácter físico de un 65 por ciento como mínimo, estén o no incapacitadas; c) personas con discapacidades certificadas de tipo sensorial a partir de un 65 por ciento, estén o no incapacitadas; d) personas incapacitadas por sentencia judicial firme, siempre y cuando se hayan equiparado los grados y tipos de discapacidad según la determinación legal.

La última apreciación, merece unas líneas aclaratorias. El Juez civil carece de competencia para graduar y calificar la discapacidad psí-

paración de los ámbitos de responsabilidad de las deudas; DÍEZ-PICAZO y GULLÓN añaden otras causas como las relativas a los regímenes especiales de gestión y administración (vid., Sistema de Derecho Civil I, Madrid, 2002, 10. ${ }^{a}$ ed. pp. 383 a 384; ALBALADEJO, Derecho Civil I. Introducción y Parte General, Barcelona, 2002, 15. a ed., pp. 509 a 511; COSSÍO, «La teoría del patrimonio», Estudios en homenaje al Prof. Serrano, Valladolid, 1965, págs. 125 y sigs.; FAIRÉN MARTÍNEZ, «Patrimonio y responsabilidad patrimonial», $R D N, 1962$, pp. 241 y ss.).

11 Vid., infra la mención hecha a las modificaciones tributarias y más extensamente, «Protección civil de las personas con discapacidad: patrimonio especialmente protegido y accesibilidad universal en la Propiedad Horizontal», RCDI, 687, 2005, pp. 61 a 115.

12 La variabilidad de aquellos criterios políticos y administrativos de los que dependen la adquisición y pérdida de la condición de discapacitado había sido denunciada oportunamente por el Consejo General del Poder Judicial y puesto de manifiesto en los debates parlamentarios (vid., DCG, núm. 293, 2003 VII Legislatura). 
quica, física o sensorial que padezca la persona de la que se pretende su incapacitación. Con esta máxima a la vista, debe ser revisado el contenido de la Exposición de Motivos de la Ley y la fórmula legal utilizada para la determinación de sus beneficiarios según su artículo segundo.

Por su parte, la mencionada Exposición de Motivos sienta que «beneficiarios de este patrimonio pueden ser, exclusivamente, las personas con discapacidad afectadas por unos determinados grados de minusvalía, y ello con independencia de que concurran o no en ellas las causas de incapacitación judicial contempladas en el artículo 200 del Código Civil y de que, concurriendo, tales personas hayan sido o no judicialmente incapacitadas». A esta terminante declaración, se añade el dictado del artículo segundo cuyos términos son los siguientes «1. El patrimonio protegido de las personas con discapacidad tendrá como beneficiario, exclusivamente, a la persona en cuyo interés se constituya, que será su titular. 2. A los efectos de esta Ley únicamente tendrán la consideración de personas con discapacidad: a) Las afectadas por una minusvalía psíquica igual o superior al 33 por 100. b) Las afectadas por una minusvalía física o sensorial igual o superior al 65 por 100. 3. El grado de minusvalía se acreditará mediante certificado expedido conforme a lo establecido reglamentariamente o por resolución judicial firme». En definitiva parece que excluye de las ventajas de la Ley a quienes estén incapacitados judicialmente si no tienen reconocidos los grados específicos de las tipologías de discapacidad ${ }^{13}$ en cuestión, toda vez que como se ha dicho, el Juez civil carece, de momento, de las competencias para su concreción. De lo dicho se ha de concluir que si quien pretenda ser beneficiario de la institución sólo está incapacitado judicialmente, es más que posible que la constitución del patrimonio no llegue a buen puerto.

Por ello, sobre su ámbito subjetivo es conveniente destacar los siguientes puntos: a) El legislador recurre a la figura de la discapacidad

13 Hasta la declaración que hace la mencionada Ley 39/2006, de Promoción de la Autonomía Personal y Atención a las personas en situación de dependencia, sobre la «minusvalía», nos habríamos referido de forma intercambiable bien a esta denominación como a la de «discapacidad»; sin embargo, su Disposición adicional octava, sobre terminología, advierte que "las referencias que en los textos normativos se efectúan a "minusválidos" y a "personas con minusvalía", se entenderán realizadas a las "personas con discapacidad". A partir de la entrada en vigor de la presente Ley, las disposiciones normativas elaboradas por las Administraciones Públicas utilizarán los términos "persona con discapacidad" o "personas con discapacidad" para denominarlas». 
antes que a la incapacitación judicial, por lo que adopta una nueva línea tutelar atendiendo no a los tradicionales criterios de capacidad e incapacitación sino a una institución de nuevo corte para el Derecho Civil. b) Es necesario tener en cuenta la correlación judicial entre ciertos grados de minusvalía y la estimación de la incapacitación de la persona que las padece. Esta correspondencia entre la incapacitación judicial y la discapacidad del 65 por ciento es un dato que conviene tener a la vista ya que cabe la posibilidad de que este criterio de equiparación termine por generalizarse a efectos civiles. De momento, la jurisprudencia menor consultada parece confirmar el criterio inverso, es decir, si hay reconocimiento administrativo de minusvalía procede la incapacitación con alcance absoluto o parcial ${ }^{14}$. c) La Exposición de Motivos de la Ley tenía muy presente las consecuencias de los accidentes de tráfico y laborales con la posible declaración para quien los sufra de incapacidad laboral permanente total, absoluta o gran invalidez que, a su vez, se corresponde reglamentariamente con un 33 por ciento de minusvalía. Se suman tres nociones de distinto corte como son la incapacidad laboral absoluta ${ }^{15}$, la incapacitación judicial que opera sobre la capacidad de obrar, y el reconocimiento administrativo de discapacidad, cuyas reciprocidades y

14 Vid., la Sentencia de la Audiencia Provincial Santa Cruz de Tenerife núm. 105/2004 (Sección 3 $3^{\mathrm{a}}$ ), de 12 marzo; Sentencia de la Audiencia Provincial Badajoz núm. 10/2003 (Sección 3 $3^{\mathrm{a}}$ ), de 15 enero; Sentencia de la Audiencia Provincial Valladolid núm. 383/2002 (Sección $1^{\mathrm{a}}$ ), de 15 noviembre y Sentencia de la Audiencia Provincial Ciudad Real núm. 145/2002 (Sección $1^{\text {a }}$ ), de 6 mayo. Por su parte, la Sentencia del Tribunal Superior de Justicia de Navarra núm. 127/2003 (Sección de lo Social), de 30 de abril de 2003, declara que «el umbral de estas deficiencias (se refiere a las psíquicas, físicas o sensoriales) se encuentra en el 33 por ciento — similar a la incapacidad parcial—».

${ }^{15}$ Como exponente de las anteriores consideraciones, vamos a traer a colación la Sentencia de la Audiencia Provincial de Cádiz de 9 de marzo de 2004; esta resolución evidencia la superposición —o, en todo caso, la presencia simultánea- de la incapacitación judicial, invalidez laboral y los distintos tipos y grados de minusvalía. En el caso de autos, el presunto incapaz es un empresario que sufrió un grave accidente de tráfico; previo al procedimiento de incapacitación, se había dictado sentencia de separación fundada en las perturbaciones mentales deducidas del accidente en cuestión y, por su parte, se le había reconocido laboralmente una invalidez permanente absoluta para el ejercicio de cualquier actividad. Si bien la resolución no entra al fondo de la cuestión por un defecto del petitum, el juzgador declara que pese a las secuelas físicas que siguieron al accidente «no puede darse lugar a la declaración de discapacidad a los efectos del artículo 2 de la Ley de Patrimonios Protegidos, al no haber sido una pretensión oportunamente deducida, sino meramente apuntada en la vista del presente recurso. El goce de los beneficios que la citada Ley proclama podrá ser obtenido con relativa facilidad a través de la calificación administrativa de su minusvalía». En el caso de autos, fue instaurada una curatela limitada a la esfera patrimonial [vid., Sentencia de la Audiencia Provincial Cádiz núm. 14/2004 (Sección 4ª), de 9 marzo]. 
equivalencias están reconocidas a efectos fiscales y de cobertura de la Seguridad Social ${ }^{16}$.

En suma, pueden ser beneficiarios quienes tengan los pertinentes grados de discapacidad reconocidos, estén o no incapacitados judicialmente, y también pese a la mejorable redacción legal, quienes hayan sido incapacitados por sentencia judicial firme en aplicación del artículo 200 del Código Civil ${ }^{17}$, siempre y cuando ostenten acre-

16 Téngase en cuenta, por su parte, la Ley 40/2007, de 4 de diciembre, de medidas en materia de Seguridad Social que, en Disposición adicional novena, declara lo siguiente: «Asimilación de las personas que judicialmente hayan sido declaradas incapaces. A los efectos de la aplicación de la Ley General de la Seguridad Social, se entenderá que están afectadas por una discapacidad en un grado igual o superior al 65 por ciento, aquellas personas que judicialmente hayan sido declaradas incapaces». Por su parte, a los efectos del Impuesto sobre la Renta de las Personas Físicas, el artículo 58.6 declara que «tendrán la consideración de discapacitados los contribuyentes que acrediten, en las condiciones que reglamentariamente se establezcan, un grado de minusvalía igual o superior al 33 por 100. En particular, se considerará acreditado un grado de minusvalía igual o superior al 33 por 100 en el caso de los pensionistas de la Seguridad Social que tengan reconocida una pensión de incapacidad permanente total, absoluta o gran invalidez y en el caso de los pensionistas de clases pasivas que tengan reconocida una pensión de jubilación o retiro por incapacidad permanente para el servicio o inutilidad. Igualmente, se considerará acreditado un grado de minusvalía igual o superior al 65 por 100, cuando se trate de minusválidos cuya incapacidad sea declarada judicialmente, aunque no alcance dicho grado» (Real Decreto Legislativo 3/2004, de 5 de marzo, por el que se aprueba el Texto Refundido de la Ley del Impuesto sobre la Renta de las Personas Físicas). Equiparación compartida por las prescripciones del artículo primero de la Ley 51/2003, de 2 de diciembre, de igualdad de oportunidades, no discriminación y accesibilidad universal de las personas con discapacidad, tal y como se argumenta en las líneas dedicadas al ámbito subjetivo de aplicación de esta Ley.

17 Ha de tenerse en cuenta que son dos capítulos diferentes y que en varias ocasiones, la alegación del grado de minusvalía reconocido como fundamento de la incapacitación judicial interesada, ha sido desestimada por no vincular al juzgador ni cumplir con las exigencias del artículo 200 del Código Civil (vid., Sentencia del Tribunal Supremo de 14 mayo de 2003). En los comentarios sobre la Ley, no parecen especialmente afortunadas las afirmaciones que entienden que los términos de discapaz e incapacitado se utilicen de forma indistinta. En realidad, más parece que el legislador desea superar la noción de incapacitación e ir en la dirección de unos baremos como los aprobados en materia de accidentes de tráfico. Pero, en todo caso, al día de hoy no podemos concluir que la Ley utilice ambos términos como sinónimo; LUCINI NICÁS, por su parte entiende que pese a la univocidad terminológica, no es posible confundir incapacidad con discapacidad (vid., op. cit.). Finalmente, conviene tener en cuenta que la finalidad de las normas sobre ciertos conceptos relacionados con la materia, no es idéntica; por ello, previo a la promulgación de la normativa que hace sinónimos ciertas situaciones, se había sostenido que la pretensión de la persona declarada en situación de incapacidad permanente total para su profesión habitual de que se le reconozca el grado de minusvalía del 33 por ciento, consagraría situaciones de desigualdad carentes de de justificación objetiva (vid., STSJ de Madrid de 8 de marzo de 2001). 
ditación de alguno de los grados y tipos reseñados ${ }^{18}$. Por su parte, juzgados de primera instancia y audiencias ya han tenido ocasión de pronunciarse sobre el referido ámbito subjetivo destacando, en todo caso, que «el concepto de beneficiarios que contempla la Ley es notablemente más amplio al de «incapacitado» comprendiendo a las personas afectadas por una minusvalía psíquica igual o superior al 33 por ciento y a las afectadas por una minusvalía física o sensorial igual o superior al 65 por ciento (artículo 2 de la Ley)» ${ }^{19}$. Finalmente, el número de potenciales beneficiarios de los incentivos de la Ley se fijaba, según la Memoria económica del Anteproyecto, en un dos por ciento del millón de personas que padecen algún tipo de discapacidad. En esta ocasión, y, frente a la distribución directa entre los comuneros que apareja la modificación de la Propiedad Horizontal, el reparto del riesgo social es de tipo indirecto. Específicamente, el coste recaudatorio para la Hacienda Pública ha sido cuantificado en unos cuarenta millones de euros ${ }^{20}$.

\section{LOS SUJETOS CONSTITUYENTES Y APORTANTES: BIENES Y DERECHOS SUSCEPTIBLES DE FORMAR PARTE DE LA MASA PATRIMONIAL}

\subsection{Tipos y clases de sujetos constituyentes}

Podrán constituir este patrimonio protegido, en principio, aquellas personas con discapacidad según el grado y tipos señalados estén o no incapacitadas judicialmente. En caso de que lo estén, dejando a salvo los límites sobre su capacidad de obrar fijados por la sentencia judicial y, en presencia de esta objeción, los órganos tuitivos titulares. En caso de que presenten discapacidad física o sensorial y al tiempo,

18 Conviene tener presente ciertos pronunciamientos judiciales que recuerdan que la calificación que realicen los órganos técnicos competentes será independiente de la realizada por otros organismos públicos (vid., STSJ del País Vasco de 10 de septiembre de 2002 y STSJ de Madrid, de 8 de marzo de 2001).

19 Auto de la Audiencia Provincial Cáceres núm. 28/2004 (Sección 1ª), de 12 marzo, dictado con ocasión del recurso de apelación interpuesto contra la propuesta de auto dimanante del procedimiento sobre enajenación de bienes de incapaz.

${ }^{20}$ La disparidad con las cifras que computaban más de tres millones y medio de personas con discapacidad, obedece a que en la Memoria se incluye estrictamente quien ostente el grado de minusvalía reconocido. Concretamente el entonces Ministro de Trabajo y Asuntos Sociales Sr. Zaplana, cuantificaba según los datos del censo de 2001 en casi un millón y medio de personas con alguna discapacidad (1.445.697 españoles, 1.067 .873 con discapacidad psíquica y 377.824 con discapacidad física o sensorial). 
carezcan de capacidad de obrar, podrán interesar su constitución padres, tutores y curadores. En el supuesto de que la persona con discapacidad lo sea por razón de discapacidad psíquica, la ley autoriza además a sus guardadores de hecho ${ }^{21}$ en previsión de que si a la muerte de sus padres, el sujeto fuera beneficiario de algunas pólizas suscritas por sus mayores, a falta de sentencia de incapacitación aquellos tengan autorización legal para integrar tales pensiones en el patrimonio 22 .

En definitiva, podrán constituir la masa patrimonial, teniendo además la condición de sujeto constituyente: a) La persona con discapacidad reconocida si no está incapacitada judicialmente; b) Los padres, tutores o curadores, si la persona con discapacidad física o sensorial, carece de plena capacidad de obrar; c) Los padres, tutores, curadores y guardadores de hecho ${ }^{23}$, si la persona con discapacidad psíquica carece de plena capacidad de obrar; d) La persona incapacitada judicialmente, que además de ostentar alguno de los tipos de discapacidad reconocida, en la sentencia de incapacitación haya sido graduada su capacidad de obrar en el ámbito patrimonial y conserve esta cualidad.

Es posible también la constitución a iniciativa de tercero, con el requisito inexcusable de que realice la oportuna aportación, teniendo en esta ocasión la condición de sujeto constituyente bien la autoridad judicial o la propia persona con discapacidad: a) La autoridad judi-

${ }^{21}$ En la materia sigo, por todos, la doctrina de mi Maestro, el Profesor LASARTE ÁLVAREZ y sus Principios de Derecho Civil. Sobre la guarda de hecho, vid., los artículos 303 y siguientes del Código civil; para su análisis desde la perspectiva de los mayores como sujetos protegidos, TEJEDOR MUÑOZ, "Acogimiento de personas mayores y guarda de hecho», LASARTE ÁLVAREZ, (Dir.), La protección de las personas mayores, Madrid, 2007, pp. 234 y ss.; también NUÑEZ MUÑIZ, «La guarda de hecho», $R D P, 1999$ y ROGEL VIDE, La guarda de hecho, Madrid, 1986; también vid., SALAS MURILLO, Responsabilidad civil e incapacidad: la responsabilidad civil por daños causados por personas en las que concurre causa de incapacitación, Valencia, 2003. Así como el texto de la Comunicación de la autora de estas líneas y la bibliografía allí citada sobre: «El guardador de hecho y el reconocimiento de la situación de dependencia y del derecho a las prestaciones: revisión de los procedimientos autonómicos y de las declaraciones efectuadas bajo su responsabilidad», presentada al Congreso Nacional: Derecho y Discapacidad.

22 Vid., RIVERA ÁLVAREZ, op. cit. n. 11, p. 94.

23 La constitución del patrimonio por parte de los guardadores de hecho, podrá realizarse observando los requisitos y limitaciones del artículo 3.1 c) de la norma que declara lo siguiente «el guardador de hecho de una persona con discapacidad psíquica podrá constituir el patrimonio protegido con los bienes que sus padres o tutores le hubieran dejado por título hereditario o hubiera de recibir en virtud de pensiones constituidas por aquellos y en los que hubiera sido designado beneficiario; todo ello sin perjuicio de lo dispuesto en los artículos 303, 304 y 306 del Código Civil». 
cial, pese a la oposición del beneficiario, padres o tutores, en los casos en que un tercero sea el solicitante. De la intelección del artículo tercero no cabe sino entender que constituyente es el Juez y el tercero no es más que un solicitante de su constitución ${ }^{24}$; b) la persona con discapacidad o, en su caso, las instituciones tutelares antes enunciadas, a iniciativa del tercero ${ }^{25}$.

En todo caso, si la constitución se realiza por resolución judicial, no ha lugar a cuestionarse la equívoca situación de la persona con discapacidad e insuficiente capacidad de obrar. Esta actuación judicial como las que en su caso puedan suscitarse con ocasión del Patrimonio Protegido, «se tramitarán como actos de jurisdicción voluntaria sin que la oposición que pudiera hacerse a la solicitud promovida se transforme en contencioso el expediente ${ }^{26}$.

En los supuestos en que se recurra al documento público, será el notario quien deba revisar, en el ejercicio de su competencia, si la persona con discapacidad no incapacitada judicialmente, posee o no suficiente capacidad de obrar para proceder a la efectiva y válida constitución del patrimonio ${ }^{27}$.

${ }^{24}$ Por su parte, la redacción literal del artículo tercero de la Ley en su punto 2 afirma: «Cualquier persona con interés legítimo podrá solicitar de la persona con discapacidad o, en caso de que no tenga capacidad de obrar suficiente, de sus padres, tutores o curadores, la constitución de un patrimonio protegido, ofreciendo al mismo tiempo una aportación de bienes y derechos adecuados, suficiente para ese fin. En caso de negativa injustificada de los padres o tutores, el solicitante podrá acudir al fiscal, quien instará del juez lo que proceda atendiendo al interés de la persona con discapacidad. Si el juez autorizara la constitución del patrimonio protegido, la resolución judicial determinará el contenido a que se refiere el apartado siguiente de esta Ley. El cargo de administrador no podrá recaer, salvo justa causa, en el padre, tutor o curador que se hubiera negado injustificadamente a la constitución del patrimonio protegido".

${ }_{25}$ Es este el lugar de cuestionarse la iniciativa de la constitución por parte de quien ocupe la dirección de un centro residencial en que la persona esté ingresado, baste la mención y la remisión a otros trabajos de la autora en materia de Residencias y específicamente en el supuesto de personas mayores, vid., «La intervención judicial en los internamientos psiquiátricos: cuestiones sobre su aplicabilidad a los ingresos no voluntarios en residencias de mayores», Cuestiones actuales de la jurisdicción en España, I. La extensión y límites de la jurisdicción y los órdenes jurisdiccionales. 1. Competencia de los órganos del orden civil, Real Academia de Jurisprudencia y Legislación, Madrid 2010; «Residencias de mayores y responsabilidad patrimonial de las Administraciones Públicas: nuevas perspectivas a la luz de la Ley española 39/2006 de Autonomía personal y atención a la dependencia», Derecho de Daños, Estudio Mario Castillo Freyre, Lima, Perú, 2010.

26 Disposición adicional primera de la Ley 41/2003.

27 Vid., el artículo 145 del Reglamento de 2 de junio de 1944, por el que se aprueba con carácter definitivo el Reglamento de la organización y régimen del notariado. 


\subsection{Aportaciones al patrimonio protegido: condiciones y título de la dotación}

Vistos los beneficiarios, que pueden coincidir o no con los sujetos constituyentes, es ahora el momento de revisar quién está autorizado legalmente para realizar aportaciones y cuáles son las condiciones materiales y el título de la dotación. En este punto, las notas características se refieren al absoluto protagonismo de la voluntad del beneficiario ya que es requisito inexcusable, como se acaba de apuntar, contar con el consentimiento de la persona con discapacidad o el de sus representantes legales.

Contando con la mencionada anuencia, sujetos aportantes pueden ser tanto los interesados como un tercero. Es muy recomendable determinar en el documento de constitución el destino de los bienes cuando se extinga el patrimonio, en especial, en previsión de la pérdida sobrevenida del grado de discapacidad exigida por la $\mathrm{Ley}^{28}$.

Por su parte, el objeto de las aportaciones puede consistir tanto en la asignación, de conformidad con el artículo 1, de bienes y derechos, como de sus frutos, productos y rendimientos. El momento de la aportación podrá ser simultánea a la constitución del patrimonio y sucesiva y posterior, exigiéndose también para éstas últimas los requisitos de la formalidad de la aportación constitutiva.

Por lo que al título se refiere, la Exposición de Motivos declara que «en todo caso, las aportaciones de terceros deberán realizarse siempre a título gratuito»; afirmación que se ve corroborada por el contenido del artículo cuarto en su punto segundo «cualquier persona con interés... podrá aportar bienes o derechos al patrimonio pro-

\footnotetext{
28 «Artículo 4. Aportaciones al patrimonio protegido.1. Las aportaciones de bienes y derechos posteriores a la constitución del patrimonio protegido estarán sujetas a las mismas formalidades establecidas en el artículo anterior para su constitución. 2. Cualquier persona con interés legítimo, con el consentimiento de la persona con discapacidad, o de sus padres o tutores o curadores si no tuviera capacidad de obrar suficiente, podrá aportar bienes o derechos al patrimonio protegido. Estas aportaciones deberán realizarse siempre a título gratuito y no podrán someterse a término. En caso de que los padres, tutores o curadores negasen injustificadamente su consentimiento, la persona que hubiera ofrecido la aportación pudiere acudir al fiscal, quien instará del juez lo que proceda atendiendo al interés de la persona con discapacidad. 3 . Al hacer la aportación de un bien o derecho al patrimonio protegido, los aportantes podrán establecer el destino que deba darse a tales bienes o derechos o, en su caso, a su equivalente, una vez extinguido el patrimonio protegido conforme al artículo 6 siempre que hubieran quedado bienes y derechos suficientes y sin más limitaciones que las establecidas en el Código Civil o en las normas de derecho civil, foral o especial, que, en su caso, fueran aplicables».
} 
tegido. Estas aportaciones deberán realizarse siempre a título gratuito y no podrán someterse a término». En su virtud, parece lo más razonable entender que cualquier aportación, independientemente de quién sea el sujeto titular del bien, deberá hacerlo a título gratuito, excluyéndose por ende los supuestos de aportaciones de bienes o derechos de titularidad de la persona discapacitada a título distinto del gratuito o a término. Sensu contrario se podrán realizar aportaciones sometidas a condición o modales.

De modo que, tanto las aportaciones de tercero - y por tercero se entiende cualquier persona distinta del beneficiario del patrimonio, incluidos los padres, tutores o curadores, constituyentes del mismo, según el dictado legal-, como las de la persona con discapacidad, deberán realizarse a título gratuito. Nada impide porque nada se prevé, acerca de la aportación de bienes muebles o inmuebles sobre los que recaiga alguna garantía, o sobre cualquier género de aportación sobre cosa gravada o capaz de suscitar gastos. Se reclama el título de la aportación, no que la aportación esté libre de cargas, por lo que en su caso habrá que recurrir al sistema previsto en el Código Civil para las donaciones modales ${ }^{29}$. Recapitulando parece, por tanto, que se podrá realizar cualquier tipo de aportación siempre y cuando el gravamen que pese sobre el bien sea inferior al valor de lo donado, siendo de aplicación el contenido de los artículos 642 y 643 del Código Civil ${ }^{30}$.

Las aportaciones, en definitiva, podrán ser dinerarias y no dinerarias; por lo que a estas últimas atañe, las modificaciones tributarias aparejadas por la Ley 41/2003, determinan unas especialidades en su tratamiento fiscal. En estos casos, la persona con discapacidad titular del patrimonio protegido, se subrogará en la posición del aportante respecto de la fecha y el valor de adquisición de los bienes y derechos $\operatorname{aportados}^{31}$.

${ }^{29}$ Sobre esta cuestión y las donaciones remuneratorias, vid., DURÁN RIVACOBA, Donación de Inmuebles. Forma y simulación, Pamplona, 2003, 2. ${ }^{a}$ ed., pp. 66 y 151 y ss.

30 «Artículo 642. Si la donación se hubiere hecho imponiendo al donatario la obligación de pagar las deudas del donante, como la cláusula no contenga otra declaración, sólo se entenderá aquél obligado a pagar las que apareciesen contraídas antes»; "Artículo 643. No mediando estipulación respecto al pago de deudas, sólo responderá de ellas el donatario cuando la donación se haya hecho en fraude de acreedores. Se presumirá siempre hecha la donación en fraude de los acreedores, cuando al hacerla no se haya reservado el donante bienes bastantes para pagar las deudas anteriores a ella».

31 Vid., artículo 16.4 a) y Disposición transitoria novena, del Real Decreto Legislativo 3/2004, de 5 de marzo, por le que se aprueba el Texto Refundido de la Ley sobre el Impuesto de la Renta de las Personas Físicas. 
Por otra parte, la Ley prevé que la mencionada adscripción del bien que sea inscribible en cualesquiera de los Registros existentes quede, a su vez, anotada en el que corresponda, como veremos. Este extremo, como otros ya mencionados, reclama nuevamente la existencia del Reglamento de desarrollo. Expresamente, la Ley prevé que pueda ser inscrito en el Registro Civil y en el de la Propiedad $^{32}$.

32 La nueva redacción del artículo 8 sobre la Constancia registral, mejora ciertas imperfecciones evidenciadas por los operadores jurídicos, así dice ahora: «Artículo 8. Constancia registral. 1. La representación legal a la que se refiere el artículo 5.7 de esta Ley se hará constar en el Registro Civil, en la forma determinada por su Ley reguladora. 2. Cuando el dominio de un bien inmueble o derecho real sobre el mismo se integre en un patrimonio protegido, se hará constar esta cualidad en la inscripción que se practique a favor de la persona con discapacidad en el Registro de la Propiedad correspondiente, conforme a lo previsto en la legislación hipotecaria. Si el bien o derecho ya figurase inscrito con anterioridad a favor de la persona con discapacidad se hará constar su adscripción o incorporación al patrimonio protegido por medio de nota marginal. La misma constancia registral se practicará en los respectivos Registros respecto de los restantes bienes que tengan el carácter de registrables. Si se trata de participaciones en fondos de inversión o instituciones de inversión colectiva, acciones o participaciones en sociedades mercantiles que se integren en un patrimonio protegido, se notificará por el notario autorizante o por el juez, a la gestora de los mismos o a la sociedad, su nueva cualidad. 3. Cuando un bien o derecho deje de formar parte de un patrimonio protegido se podrá exigir por quien resulte ser su titular o tenga un interés legítimo la cancelación de las menciones o notas marginales a que se refiere el apartado anterior. 4. La publicidad registral de los asientos a que se refiere este precepto se deberá realizar, en los términos que reglamentariamente se determinen, con pleno respeto a los derechos de la intimidad personal y familiar y a la normativa sobre protección de datos de carácter personal». La redacción recién derogada decía: "Artículo 8. Constancia registral. 1. La representación legal a la que se refiere el artículo 5.7 de esta Ley se hará constar en el Registro Civil. 2. Cuando el dominio de un bien inmueble o derecho real sobre el mismo se integre en un patrimonio protegido, se hará constar esta cualidad en la inscripción que se practique a favor de la persona con discapacidad en el Registro de la Propiedad correspondiente. La misma mención se hará en los restantes bienes que tengan el carácter de registrables. Si se trata de participaciones en fondos de inversión o instituciones de inversión colectiva, acciones o participaciones en sociedades mercantiles que se integren en un patrimonio protegido, se notificará por el notario autorizante o por el juez, a la gestora de los mismos o a la sociedad, su nueva cualidad. 3. Cuando un bien o derecho deje de formar parte de un patrimonio protegido se podrá exigir por quien resulte ser su titular o tenga un interés legítimo la cancelación de las menciones a que se refiere el apartado anterior». 
EL PATRIMONIO PROTEGIDO DE LAS PERSONAS CON DISCAPACIDAD...

\section{RÉGIMEN DE ADMINISTRACIÓN Y SUPERVISIÓN DEL PATRIMONIO PROTEGIDO}

\subsection{El sistema de administración voluntaria y convencional: la exclusión de la subasta pública}

El régimen de la administración del patrimonio estará dispuesto por el sujeto constituyente o por tercero. En todo caso, como cuestión previa recogida en la propia Exposición de Motivos, el legislador no ha querido entrar en el deslinde y calificación de los actos de administración frente a los de disposición, declarando que «en cuanto a la administración del patrimonio, y el término administración se emplea aquí en el sentido más amplio, comprensivo también de los actos de disposición, se parte de la regla general de que todos los bienes y derechos, cualquiera que sea su precedencia, se sujetan al régimen de administración establecido por el constituyente del patrimonio ${ }^{33}$. Pese a ello y probablemente ante esta indeterminación técnica, una de las cuestiones que ha tenido que ser aclarada por la reforma de la Ley 41/2003, ha sido precisamente, la noción de actos de disposición, incorporándose por la Ley 1/2009, un párrafo adicional al artículo 5 que declara: «En todo caso, y en consonancia con la finalidad propia de los patrimonios protegidos de satisfacción de las necesidades vitales de sus titulares, con los mismos bienes y derechos en él integrados, así como con sus frutos, productos y rendimientos, no se considerarán actos de disposición el gasto de dinero y el consumo de bienes fungibles integrados en el patrimonio protegido, cuando se hagan para atender las necesidades vitales de la persona beneficiaria».

Tanto el nombramiento como las facultades de la administración pueden recaer en el propio sujeto constituyente o un tercero nombrado por aquél ${ }^{34}$. En todo caso, serán de aplicación los supuestos de

33 Exposición de Motivos, IV de la Ley. Para un análisis más detallado sobre estos aspectos nos remitimos a AMUNÁTEGUI RODRÍGUEZ, Incapacitación y mandato, Madrid, 2008; «La constitución de un patrimonio protegido por las personas mayores inicialmente capaces en previsión de su futura pérdida de capacidad», Libro Homenaje al Prof. AMORÓS GUARDIOLA, I, Madrid, 2006, pp. 77 a 110; SÁNCHEZ-CALERO ARRIBAS, «La administración y la supervisión del patrimonio protegido creado por la ley 41/2003, de 18 de noviembre, de protección patrimonial de las personas con discapacidad», $R C D I, 82,695,2006$, pp. 1.057 a 1.100. También nos remitimos al trabajo específico de la autora de estas líneas, MORETÓN SANZ, «La figura del administrador del patrimonio especialmente protegido: reflexiones sobre su régimen jurídico", en PAU PADRÓN (Coord.), Libro Homenaje AMORÓS GUARDIOLA, Madrid, 2006, pp. 1.185 a 1.208 .

${ }^{34}$ La norma no oculta la intención de favorecer la intervención de instituciones sin ánimo de lucro especializadas en la atención a personas con discapacidades. 
autorización judicial de los artículos $271^{35}$ a $272^{36}$ del Código Civil pero excluyéndose expresamente la subasta pública prevista en la Ley de Enjuiciamiento Civil ${ }^{37}$. Este precepto ya ha sido aplicado analógicamente y ha permitido la enajenación de bienes de la persona incapacitada judicialmente sin necesidad de que el procedimiento pase necesariamente por pública subasta ${ }^{38}$.

35 «Artículo 271. El tutor necesita autorización judicial: 1. Para internar al tutelado en un establecimiento de salud mental o de educación o formación especial. 2. Para enajenar o gravar bienes inmuebles, establecimientos mercantiles o industriales, objetos preciosos y valores mobiliarios de los menores o incapacitados, o celebrar contratos o realizar actos que tengan carácter dispositivo y sean susceptibles de inscripción. Se exceptúa la venta del derecho de suscripción preferente de acciones. 3. Para renunciar a derechos, así como transigir o someter a arbitraje cuestiones en que el tutelado estuviese interesado. 4. Para aceptar sin beneficio de inventario cualquier herencia, o para repudiar ésta o las liberalidades. 5. Para hacer gastos extraordinarios en los bienes. 6. Para entablar demanda en nombre de los sujetos a tutela, salvo en asuntos urgentes o de escasa cuantía. 7. Para ceder bienes en arrendamiento por tiempo superior a seis años. 8 . Para dar y tomar dinero a préstamo. 9. Para disponer a título gratuito de bienes o derechos del tutelado. 10. Para ceder a terceros los créditos que el tutelado tenga contra él, o adquirir a título oneroso los créditos de terceros contra el tutelado».

36 «Artículo 272. No necesitarán autorización judicial la partición de herencia ni la división de cosa común realizadas por el tutor, pero una vez practicadas requerirán aprobación judicial».

37 Vid., sobre la tutela y las funciones del tutor en general, LEONSEGUI GUILLOT, «La tutela», Curso sobre la protección jurídica del menor, POUS DE LA FLOR y TEJEDOR MUÑOZ (Coords.), Madrid, 2001, pp. 99 y ss.

38 En este sentido, en un procedimiento sobre enajenación de bienes del incapaz, se ha declarado que «de esta manera, entiende la Sala que la prescripción comprensiva de la innecesariedad de la pública subasta, así como de la no aplicación del Título XI del Libro III de la Ley de Enjuiciamiento Civil de 1.881, viene referida exclusivamente a la enajenación de los bienes o derechos que integran el patrimonio protegido, sin que, por tanto, suponga ni la derogación tácita del artículo 2.015 de la Ley de Enjuiciamiento Civil de 1881, ni que este último precepto no pudiera aplicarse a las enajenaciones de menores o incapacitados. Sin embargo, y, atendiendo a los razonamientos que anteriormente se explicitaron, sí se considera que el artículo 5.2 de la Ley 41/2003, de 18 de Noviembre, de protección patrimonial de las personas con discapacidad y de modificación del Código Civil, de la Ley de Enjuiciamiento Civil y de la Normativa Tributaria con esta finalidad, es susceptible de aplicación analógica en la medida en que, con el máximo rigor, en poco o en nada difiere la naturaleza y fundamento de la venta de bienes de personas discapacitadas de la de bienes de personas declaradas judicialmente incapacitadas, de modo que, si para aquéllas es beneficioso el que se prescinda de la pública subasta en la enajenación de sus bienes, también habrá de serlo para éstas, si bien se estima necesario que el Órgano Jurisdiccional adopte las medidas de vigilancia y control que, en relación con la venta, estime adecuadas y pertinentes en beneficio del tutelado de conformidad con lo establecido en el artículo 233 del Código Civil». De las consideraciones antecedentes, la Audiencia estimó tanto la impugnación interpuesta por la hija y tutora del incapacitado, como la deducida por el Ministerio Fiscal, autorizándose la enajenación sin necesidad «de que se realice en pública subasta y sin perjuicio — como ya se ha indicado- de que el Juzgado de instancia adopte las medidas de vigilancia y control que, en relación con la 
Por último, y por lo que se refiere al patrimonio en sí, las sucesivas aportaciones provocarán o deberían provocar la actualización necesaria del inventario que forma parte del documento constitutivo. En todo caso, el administrador deberá dar traslado anual al Fiscal de las novedades patrimoniales que se vayan produciendo ${ }^{39}$; además, en dichos títulos de aportación habrá de hacerse la mención correspondiente sobre su adscripción al patrimonio protegido para que en el momento de su inscripción se haga la oportuna constancia registral.

\subsection{El ámbito de la supervisión: el reforzamiento del papel del Ministerio Fiscal según la Ley 1/2009}

La supervisión tiene un ámbito de aplicación distinto al de la Administración. En principio, la Ley ha previsto la posibilidad de que se simultanee un doble sistema: de una parte, la supervisión de la administración que recae en el Ministerio Fiscal con carácter preceptivo y necesario ${ }^{40}$; además de esta supervisión institucional, cabe que el

venta, estime adecuadas y pertinentes en beneficio del tutelado de conformidad con lo establecido en el artículo 233 del Código Civil». [Auto de la Audiencia Provincial de Cáceres núm. 28/2004 (Sección 1 ${ }^{\text {a)}}$, de 12 de marzo]. Últ. vid., STS de 22 de abril de 2010, que establece que los vienes heredados por menores de edad no se pueden vender sin autorización judicial o sin que ellos lo ratifiquen de forma expresa.

39 Así lo prescribe el artículo 7.2 al declarar que «cuando no sea la propia persona con discapacidad beneficiaria del patrimonio protegido o sus padres, el administrador del patrimonio protegido deberá rendir cuentas de su gestión al Ministerio Fiscal cuando lo determine éste y, en todo caso, anualmente, mediante la remisión de una relación de su gestión y un inventario de los bienes y derechos que lo formen, todo ello justificado documentalmente».

40 Esta supervisión legal, corresponde con el dictado del artículo 124 de la Constitución «1. El Ministerio Fiscal, sin perjuicio de las funciones encomendadas a otros órganos, tiene por misión promover la acción de justicia en defensa de la legalidad, de los derechos de los ciudadanos y del interés público tutelado por la ley, de oficio o a petición de los interesados, así como velar por la independencia de los Tribunales y procurar ante éstos la satisfacción del interés social. 2 El Ministerio Fiscal ejerce sus funciones por medio de órganos propios conforme a los principios de unidad de actuación y dependencia jerárquica y con sujeción, en todo caso, a los de legalidad e imparcialidad. 3. La ley regulará el estatuto orgánico del Ministerio Fiscal. 4. El Fiscal General del Estado será nombrado por el Rey, a propuesta del Gobierno, oído el Consejo General del Poder Judicial». Adicionalmente y dada la transcendencia de esta Instrucción, ha de tenerse en cuenta la número 4/2008, "Sobre el control y vigilancia por el Ministerio Fiscal de las personas discapaces», para cuya consulta nos remitimos a http://www.fiscal.es/fiscal/public/!ut/p/c1/04_SB8K8xLLM9MSSzPy8xBz9CP0os3hHP6 PQMB9TQwODsEAXA6MA88AAC29nAwN_E6B8JG55AwMCusNB9uHXD5I3wAEcDf T9PPJzU_ULciMMskwcFQHJnvPu/dl2/d1/L01DU01KSWdra2trIS9JSF JBQUlpQ2d̄Bek15cXhtL1lCSkoxTkExTkk1MC04MXcvN19BTjJVVkw1MTBPMlYwM DJQVkhQUUszMTA4 My9zYS5zcGZfQWN0aW9uTGlzdGVuZXI!/? PC_7 AN2UVL510O2V002PVHPQK31083_spf_strutsAction=!2factionManager.do!3fCS_Para 
constituyente haya establecido un sistema adicional que, por tanto, tiene naturaleza no necesaria y voluntaria.

Por lo que se refiere a las obligaciones que en esta materia corresponderán al Ministerio Fiscal, afectan a dos tipos de actuaciones según se refiera a la supervisión permanente y general o, la esporádica y concreta que entrará en aplicación cuando las circunstancias singulares de un caso particular así lo exijan. En estos supuestos, el Ministerio Fiscal instará de oficio o a instancia de persona interesada (la Exposición de Motivos se refiere a cualquier persona) la adopción por el Juez de las medidas oportunas en aras de la mejor concreción de los fines para los que el patrimonio ha sido constituido.

En las competencias y actuaciones señaladas, la Fiscalía cuenta con el apoyo, auxilio y asesoramiento de la Comisión de Protección Patrimonial de las Personas con Discapacidad. La mencionada Comisión que por prescripción legal tiene la condición de órgano externo de apoyo, auxilio y asesoramiento ha sido desarrollada por el Real Decreto $177 / 2004$, de 30 de enero, que concreta su composición, funcionamiento y funciones ${ }^{41}$, Real Decreto modificado, a su vez, por el

m\%3dcid\%253D1213708237653\%2526pagename\%253DPortalFiscal\%25252FPaginaP F\%25252FwpsPortalFiscal_2008PFTpl_xml\%2526c\%253DPaginaPF\# AN2UVL510O2V002PVHPQK31083

${ }^{41}$ La Exposición de Motivos de la Ley 41/2003 declara sobre la supervisión «aspecto fundamental del contenido de la Ley es el de la supervisión de la administración del patrimonio protegido de las personas con discapacidad. El primer aspecto que destaca de esta supervisión es que el constituyente puede establecer las reglas de supervisión y fiscalización de la administración del patrimonio que considere oportunas. En segundo lugar, la supervisión institucional del patrimonio protegido corresponde al Ministerio Fiscal, respecto del cual se prevén dos tipos de actuaciones, a saber: a) Una supervisión permanente y general de la administración del patrimonio protegido, a través de la información que, periódicamente, el administrador debe remitirle. b) Una supervisión esporádica y concreta, ya que cuando las circunstancias concurrentes en un momento determinado lo hicieran preciso, el Ministerio Fiscal puede solicitar del juez la adopción de cualquier medida que se estime pertinente en beneficio de la persona con discapacidad. A estos efectos, el Ministerio Fiscal puede actuar tanto de oficio como a solicitud de cualquier persona, y será oído en todas las actuaciones judiciales que afecten al patrimonio protegido, aunque no sean instadas por él. Por otro lado, la Ley crea la Comisión de Protección Patrimonial de las Personas con Discapacidad, cuya función básica es ser un órgano externo de apoyo, auxilio y asesoramiento del Ministerio Fiscal en el ejercicio de sus funciones, sin perjuicio de las demás que reglamentariamente pudieran atribuírsele». Declaración que se traduce en el contenido del artículo 7. «1. La supervisión de la administración del patrimonio protegido corresponde al Ministerio Fiscal, quien instará del juez lo que proceda en beneficio de la persona con discapacidad, incluso la sustitución del administrador, el cambio de las reglas de administración, el establecimiento de medidas especiales de fiscalización, la adopción de cautelas, la extinción del patrimonio protegido o cualquier otra medida de análoga naturaleza. El Ministerio Fiscal actuará de oficio o a solicitud de cualquier persona, y será oído en todas las actua- 
2.270/2004, de 3 de diciembre, que actualizó su composición a tenor de la reestructuración de los departamentos ministeriales, de una parte, y adscribió la Comisión al Ministerio de Trabajo y Asuntos Sociales, a través de la Secretaría de Estado de Servicios Sociales, Familias y Discapacidad. Con todo la reforma de la Ley 41/2003, la adscribió, con ocasión de los cambios ministeriales al Ministerio de Educación, Política Social y Deporte en la actualidad es el Ministerio de Sanidad y Política Social, al quedar adscrita, según el RD 1853/2009, de 4 de diciembre y reforzó la participación preceptiva, ahora de la Fiscalía, así como de «representantes de la asociación de utilidad pública más representativa en el ámbito estatal de los diferentes tipos de discapacidad».

\section{EL CONTENIDO MÍNIMO DEL DOCUMENTO CONSTITUTIVO: LA PUBLICIDAD REGISTRAL}

\subsection{Documento constitutivo y formalidades imperativas}

La constitución del patrimonio resulta del documento público notarial o, en su caso, judicial, sin otros trámites que la consignación en la escritura o en la resolución de ciertas prescripciones ordenadas por el artículo $3.3^{42}$. Títulos ambos suficientes para la oportuna cons-

ciones judiciales relativas al patrimonio protegido. 2. Cuando no sea la propia persona con discapacidad beneficiaria del patrimonio o sus padres, el administrador del patrimonio protegido deberá rendir cuentas de su gestión al Ministerio Fiscal cuando lo determine éste y, en todo caso, anualmente, mediante la remisión de una relación de su gestión y un inventario de los bienes y derechos que lo formen, todo ello justificado documentalmente. El Ministerio Fiscal podrá requerir documentación adicional y solicitar cuantas aclaraciones estime pertinentes. 3. Como órgano externo de apoyo, auxilio y asesoramiento del Ministerio Fiscal en el ejercicio de las funciones previstas en este artículo, se crea la Comisión de Protección Patrimonial de las Personas con Discapacidad, adscrita al Ministerio de Educación, Política Social y Deporte, [antes de la reforma operada por la Ley 1/2009 el precepto decía: Ministerio de Trabajo y Asuntos Sociales] y en la que participarán, en todo caso, el Ministerio Fiscal [esta referencia expresa a la preceptiva participación de la Fiscalía ha sido incorporada por la reforma recién mencionada] y representantes de la asociación de utilidad pública, más representativa en el ámbito estatal, de los diferentes tipos de discapacidad. La composición, funcionamiento y funciones de esta Comisión se determinarán reglamentariamente».

${ }^{42}$ Vid., art. 3, precepto al que la Ley $1 / 2009$ ha añadido un último párrafo que declara: «Los notarios comunicarán inmediatamente la constitución y contenido de un patrimonio protegido por ellos autorizado al fiscal de la circunscripción correspondiente al domicilio de la persona con discapacidad, mediante firma electrónica avanzada. Igual remisión efectuarán de las escrituras relativas a las aportaciones de toda clase, que se realicen con posterioridad a su constitución. El fiscal que reciba la comunicación de la constitución de un patrimonio protegido y no se considere competente para su fiscalización lo remitirá al fiscal que designe el Fiscal General del Estado, de acuerdo con su Estatuto Orgánico». 
tancia registral interesada por el artículo 8 ya mencionado de la Ley 41/2003 y su nueva redacción. De modo que hay que evidenciar, aunque no sea ésta la materia principal de análisis, que el documento público se convierte en una formalidad sustancial para la constitución del patrimonio, sin cuya observancia dicha masa patrimonial no habrá nacido válidamente. En todo caso, si bien inicialmente podía entenderse que no resultaba preceptiva su constancia en los Registros correspondientes a los bienes registrables, lo cierto es que los términos imperativos del artículo parece que sí lo imponen sin que el beneficiario o sus representantes puedan adoptar acuerdo que contravenga dichos términos imperativos ${ }^{43}$; con todo ha de tenerse en cuenta que esta norma no altera la regla de general del ordenamiento hipotecario español caracterizado por la inscripción declarativa del derecho real, si bien podría calificarse técnicamente que se trate, por lo que a la mención se refiere caso de que el bien esté inscrito, de una inscripción obligatoria ${ }^{44}$. Por su parte y sin duda desde un principio, la publicidad registral relativa al nombramiento del administrador deviene imperativa.

Además de las prescripciones ordinarias exigidas a un documento notarial, han de concursar unas previsiones mínimas y necesarias ante la peculiar naturaleza del patrimonio protegido. Conviene tenerlas presentes, dada su concurrencia preceptiva, ya que en su defecto, no habrá sido constituido válidamente el patrimonio en cuestión al no haber sido observadas las prescripciones legales ${ }^{45}$.

${ }^{43}$ La calificación técnica que merezca la constancia en los bienes registrables, se trata de otra de las cuestiones de interés de esta nueva institución. De una parte, como ya se ha dicho, del tenor del precepto transcrito ut supra no se puede deducir que resulte constitutiva su inscripción, de otra, la anotación que se practicará en el bien inscribible será, en principio, una indicación de su sujeción a la masa especialmente protegida.

${ }_{44}$ Vid., LASARTE ÁLVAREZ, Derechos reales y derecho hipotecario, cit.

45 Como se ha dicho, son muchos los elementos de interés que presenta la figura del patrimonio protegido de los que se ha ocupado intensamente la doctrina, así vid., BELLO JANEIRO, (Coord.), Protección jurídica y patrimonial de los discapacitados, Santiago de Compostela, 2005; CUADRADO IGLESIAS, «Reflexiones acerca del patrimonio protegido de las personas con discapacidad», GONZÁLEZ PORRAS y MÉNDEZ GONZÁLEZ (Coords.), Libro homenaje al Prof. Albaladejo, Madrid, 2005; CUBILES SÁNCHEZ-POBRE, «La protección patrimonial de las personas con discapacidad en la Ley 41/2003, de 18 de noviembre», Aranzadi fiscal, 5, 2005, pp. 1 y ss.; HERBOSA MARTÍNEZ, «El patrimonio especial del discapacitado en la Ley 41/2003, de 18 de noviembre, de Protección Patrimonial de las Personas con Discapacidad», $A C, 16,2005$; LÓPEZ-GALIACHO PERONA, «Aportaciones al estudio del llamado patrimonio protegido del discapacitado», RCDI, 687, 2005, pp. 31 a 60; RUBIO TORRANO, «El patrimonio del discapacitado», en BELLO JANEIRO (Coord.), Protección jurídica y patrimonial de los discapacitados, cit., pp. 321 y ss.; LINACERO DE LA FUENTE, Protección jurídica de personas con discapacidad, menores desfavorecidos y 
En definitiva, al contenido ordinario se añade el específico, de modo que el documento de constitución tendrá que recoger, de conformidad al tenor literal del artículo 3.3 los siguientes elementos con carácter necesario e imperativo: a) El inventario de bienes y derechos que inicialmente constituyan el patrimonio protegido; b) la determinación de las reglas de administración, incluyendo los procedimientos de designación de las personas que hayan de integrar los órganos de administración o, en su caso, de fiscalización; c) a su vez, y ante la exigencia del artículo 5.2, entre dichas reglas de administración se habrá de incluir, necesariamente, en los supuestos de ausencia de capacidad suficiente del beneficiario, la obligatoriedad de autorización judicial en los casos ya prevenidos para el tutor en los artículos 271 y 272 del Código civil ${ }^{46}$, incluida la retribución y las indemnizaciones que puedan corresponder al administrador por razón de sus funciones ${ }^{47}$. Dichas cargas parece que habrán de ser preferentemente satisfechas de una fuente de financiación distinta al

personas mayores, Madrid, 2004; PASTOR ÁLVAREZ, «Una nueva estrategia legal ante la discapacidad: la protección patrimonial de las personas discapacitadas», Aranzadi Civil, 20, 2004; PÉREZ JIMÉNEZ, «Algunas reflexiones en torno a la Ley 41/2003, de 18 de noviembre, de Protección Patrimonial de las personas con discapacidad», $A C$, 21, 2004, pp. 2.540 a 2.558; PEREÑA VICENTE, «El incapacitado ante la nueva protección jurídica del discapacitado», $A C$, 15, septiembre, 2004;; SERRANO GARCÍA, "Discapacidad e incapacidad en la Ley 41/2003, de 18 de noviembre», RJN, 52, 2004, pp. 231 a 271; ZURITA MARTÍN, Protección civil de la ancianidad, Madrid, 2004; CORRAL GARCÍA, «Algunas consideraciones sobre la protección de las personas mayores por el Derecho civil: en especial, el papel del notario como garante de la capacidad de los mayores», RJC, 46, 2003, pp. 27 a 65.

${ }^{46}$ Las partes, a iniciativa propia o, en su caso, a instancia notarial o judicial, también podrán recoger otras disposiciones relativas a la administración o conservación, como por ejemplo el régimen de organización de la administración caso de que el cargo recaiga colectivamente en una pluralidad de sujetos; otras fórmulas para la incorporación subsiguiente de nuevos bienes o derechos que, en un futuro, se puedan sumar al patrimonio; el régimen de las cargas que recaigan sobre los bienes, etc. En resumidas cuentas, se podrá añadir «cualquier otra disposición que se considere oportuna respecto a la administración o conservación del mismo».

47 El Profesor SERRANO GARCÍA pone de manifiesto las consecuencias, caso de desafección del bien al patrimonio, de la falta de cumplimiento de este requisito ya que «resultará que el registrador, cuando califique una escritura de enajenación o gravamen de un bien inmueble o derecho real integrante del patrimonio protegido, denegará la inscripción si no viene acompañada de la pertinente autorización judicial, salvo que el beneficiario del patrimonio tenga capacidad de obrar suficiente» («Discapacidad e incapacidad en la Ley 41/2003, de 18 de noviembre», cit., p. 247). Por el contrario, la ausencia de mención de este extremo en la escritura de constitución no creo que sea impedimento para su válido nacimiento, toda vez que estos preceptos referidos a la necesaria autorización judicial del tutor para la enajenación, serán aplicables hayan sido mencionados o no, dado su carácter de derecho imperativo. En todo caso, sin duda es más conveniente hacer expresión del caso. 
propio patrimonio, extremo este último que contribuye a la finalidad legal tuitiva de la persona con discapacidad ${ }^{48}$.

\subsection{El Registro civil y la reforma de la Ley 1/2009}

En cuanto atañe a la publicidad registral la Ley, expresamente, contempla la inscripción en el Registro Civil del nombramiento del administrador —en definitiva como representante legal del beneficiario en lo que afecte al patrimonio - y, como hemos dicho, en el de la Propiedad o el correspondiente la afección de los bienes y derechos al patrimonio protegido.

Habíamos criticado que la falta de desarrollo reglamentario dificultaba pero, en absoluto, impedía los trámites dirigidos a la constitución de un patrimonio ${ }^{49}$. En este sentido, el dictado original que determinaba en su artículo 8 esta constancia registral, ha sido objeto de reforma con ocasión de la Ley 1/2009, para salvar los obstáculos que se presentaban en el Registro civil, así ahora declara: «8.1. La representación legal a la que se refiere el artículo 5.7 de esta Ley se hará constar en el Registro Civil, en la forma determinada por su Ley reguladora ${ }^{50}$. De modo que si el cargo del administrador no recae sobre el beneficiario y ostentando como ostenta aquél la condición de representante legal del titular del patrimonio en los actos que se refieran a esta masa patrimonial, el legislador ha resuelto que se dé publicidad de este nombramiento.

Conviene reparar que con ello se dará publicidad indirecta de la discapacidad del beneficiario aun en los casos en que conserve sufi-

\footnotetext{
48 Nada dice la Ley en contra de la retribución y, por otra parte, atendiendo a razones de equidad tampoco puede resultar oneroso para quien ostente el cargo de modo que, en todo caso, tendrá derecho a ser indemnizado por los gastos en que incurra por razón de su desempeño (vid., en este sentido el artículo 274 del Código civil «el tutor tiene derecho a una retribución siempre que el patrimonio del tutelado lo permita. Corresponde al juez fijar su importe y el modo de percibirlo, para lo cual tendrá en cuenta el trabajo a realizar y el valor y la rentabilidad de los bienes, procurando en lo posible que la cuantía de la retribución no baje del cuatro por ciento ni exceda del veinte por ciento del rendimiento líquido de los bienes»).

49 Vid., MORETÓN SANZ, «La figura del administrador del patrimonio especialmente protegido: reflexiones sobre su régimen jurídico», cit., pp. 1.200 y ss.

50 Precepto que, por su parte, declara: «el administrador del patrimonio protegido, cuando no sea el propio beneficiario del mismo, tendrá la condición de representante legal de éste para todos los actos de administración de los bienes y derechos integrantes del patrimonio protegido, y no requerirá el concurso de los padres o tutor para su validez y eficacia» (art. 5.7).
} 
ciente juicio y pese a que esta condición per se no altera el estado civil. Empero la norma ha resuelto unificar la mención del cargo del administrador e, independientemente de la capacidad de obrar, si el beneficiario no es el administrador, se dará publicidad registral de esta representación por lo que al patrimonio se refiere. Con ello también se ratifica el contenido del artículo 325 del Código ya que la administración, ciertamente, concierne siquiera sea indirectamente al estado civil de las personas ${ }^{51}$. Por fin, teniendo a la vista el objeto del Registro Civil previsto en la Ley de 1957 en su primer artículo párrafo octavo que será, entre otros, «la patria potestad, tutela y demás representaciones que señale la Ley», habíamos pronosticado que el cargo del administrador, en su condición de representante legal, habría de ser inscrito, en la Sección cuarta de las tutelas y representaciones legales, Libro que específico que ahora se denominará «Libro de Incapacitaciones, cargos tutelares y administradores de Patrimonios protegidos ${ }^{52}$. También con la reforma resuelve la duda sobre el Registro competente y aclara que será el del domicilio del incapacitado o del beneficiario del patrimonio protegido ${ }^{53}$.

51 Declara el artículo 325 del Código civil que «los actos concernientes al estado civil de las personas se harán en el Registro destinado a este efecto».

52 Dice la Ley 1/2009: Cuatro. Se añade un nuevo artículo 46 bis con la siguiente redacción: «Los encargados de los Registros Civiles Municipales extenderán por duplicado las inscripciones marginales de la Sección I sobre las modificaciones judiciales de capacidad, así como las inscripciones de la Sección IV sobre constitución y modificación de organismos tutelares, prórroga o rehabilitación de la patria potestad, medidas judiciales sobre guarda o administración de presuntos incapaces o menores no sujetos a patria potestad, vigilancia o control de tales cargos, documentos públicos de autotutela, y las de constitución de patrimonio protegido y de designación y modificación de administradores de patrimonios protegidos, uno de cuyos ejemplares será remitido al Registro Civil Central para su extensión en el Libro de Incapacitaciones, cargos tutelares y administradores de Patrimonios Protegidos. Las inscripciones a que se refiere el párrafo precedente se practicarán en virtud de comunicación remitida de oficio, junto con testimonio bastante de la resolución recaída, por el Juez competente, de conformidad con lo previsto por la Ley de Enjuiciamiento Civil, o bien mediante testimonio bastante de la escritura de constitución del patrimonio protegido o de designación y modificación de administradores de patrimonios protegidos que el juez o el notario autorizante deberá remitir en el plazo máximo de tres días al Encargado del Registro Civil competente, que lo será, respecto de las inscripciones que se hayan de practicar en la Sección IV, el del domicilio del incapacitado o beneficiario del patrimonio protegido».

53 En todo caso téngase presente lo previsto en los artículos 283 a 292 del Reglamento del Registro Civil por cuanto concretan, a su vez, el régimen de inscripciones y anotaciones de la Sección de Tutelas y Representaciones legales, así como el modelo no impreso número 25 de la Orden de 24 de diciembre de 1958 sobre «Inscripción principal de representación legal no tutelar». En suma, caso de que se pudiera utilizar este procedimiento, en esta inscripción se expresará a quién o quiénes corresponde el cargo de administrador respecto del patrimonio protegido, así como la fecha de 
Con esta publicidad se consiguen idénticos efectos que los perseguidos por los artículos 218 y 219 del Código civil ${ }^{54}$, por lo que cabe deducir que en tanto en cuanto no figure inscrito el cargo del administrador del patrimonio (dándose publicidad de su titularidad y de su aceptación) no serán oponibles a terceros, ni su nombramiento ni los efectos de las operaciones que realice en el ejercicio de su competencia ${ }^{55}$.

\section{LA EXTINCIÓN DEL PATRIMONIO PROTEGIDO: DESTINO DE LOS BIENES Y DERECHOS APORTADOS}

\subsection{Causas de extinción: legales y convencionales}

Las causas que producirán por imperativo legal la extinción del patrimonio, son las siguientes: A) Por determinación judicial cuando así convenga a los intereses de la persona con discapacidad; B) por muerte del beneficiario; C) Por declaración de fallecimiento del beneficiario; D) o por dejar de padecer la minusvalía en el grado mínimo exigido.

En caso de que la extinción se produzca por muerte o declaración de fallecimiento, si no ha sido dispuesta otra cosa al realizar la aportación, la totalidad del patrimonio se entenderá por prescripción legal, comprendido en su herencia. Si la causa de extinción del patrimonio obedece a una pérdida sobrevenida de la condición prescrita en la Ley para ser titular, en estos supuestos el antiguo titular y beneficiario del patrimonio protegido continuará con la titularidad de los bienes adscritos al patrimonio, también salvo que haya sido acordado otro destino por quien o quienes realizaron las aportaciones en su momento.

aceptación del cargo en virtud del documento notarial o la resolución judicial que corresponda. En cuanto a la tutela legal de las entidades públicas vid., la Resolución de 22 de junio de 1996.

54 El texto del artículo 218 dice: «Las resoluciones judiciales sobre los cargos tutelares y de curatela habrán de inscribirse en el Registro Civil.- Dichas resoluciones no serán oponibles a terceros mientras no se hayan practicado las oportunas inscripciones». Por su parte, el artículo 219 señala que «la inscripción de las resoluciones a que se refiere el artículo anterior, se practicará en virtud de la comunicación que la autoridad judicial deberá remitir sin dilación al Encargado del Registro Civil».

55 Sobre el principio de inoponibilidad de lo inscrito o incolumidad del tercero respecto del hecho no inscrito, vid., DÍAZ FRAILE, «El valor jurídico de la inscripción en el Registro Civil español», BIMJ, 2002, 56, pp. 13 y ss. 


\subsection{Destino de los bienes en caso de extinción: relevancia de la autonomía de la voluntad privada}

De los datos anteriores, hay que destacar nuevamente la relevancia atribuida por el legislador a la autonomía de la voluntad privada del aportante, ya que el régimen previsto en el artículo sexto sólo será de aplicación si no ha sido dispuesto un régimen específico. El único límite al destino que se deba dar a los bienes aportados en caso de extinción de la masa especialmente protegida, se refiere a la observación contenida en el artículo cuarto in fine que recuerda que será posible dar el destino previsto en el momento de la aportación «siempre que hubieran quedado bienes y derechos suficientes y sin más limitaciones que las establecidas en el Código Civil o en las normas de derecho civil, foral o especial, que en su caso, fueran aplicables».

En definitiva, el aportante deberá ser especialmente cuidadoso a la hora de acordar el destino que se deba dar a los bienes aportados ${ }^{56}$. Gracias a esta reversibilidad de la aportación, el otorgante garantiza que el bien o derecho en cuestión revierta nuevamente en su patrimonio, una vez cumplida la finalidad de atender al sujeto beneficiario.

\subsection{Notas sobre la fiscalidad del patrimonio protegido y el recurso de inconstitucionalidad aún irresuelto}

El tratamiento fiscal del patrimonio especialmente protegido favorece tanto su constitución como las fases subsiguientes ${ }^{57}$. Es decir, hay exenciones también en posteriores aportaciones y en la aplica-

56 «Artículo 6. Extinción. 1. El patrimonio protegido se extingue por la muerte o declaración de fallecimiento de su beneficiario o por dejar éste de tener la condición de persona con discapacidad de acuerdo con el artículo 2.2 de esta Ley. 2. Si el patrimonio protegido se hubiera extinguido por muerte o declaración de fallecimiento de su beneficiario, se entenderá comprendido en su herencia. Si el patrimonio protegido se hubiera extinguido por dejar su beneficiario de cumplir las condiciones establecidas en el artículo 2.2 de esta Ley éste seguirá siendo titular de los bienes y derechos que lo integran, sujetándose a las normas generales del Código Civil o de derecho civil, foral o especial, que, en su caso, fueran aplicables. 3. Lo dispuesto en el apartado anterior se entiende sin perjuicio de la finalidad que, en su caso, debiera darse a determinados bienes y derechos, conforme a lo establecido en el artículo 4.3 de esta Ley. En el caso de que no pudiera darse a tales bienes y derechos la finalidad prevista por sus aportantes, se les dará otra, lo más análoga y conforme a la prevista por éstos, atendiendo, cuando proceda, a la naturaleza y valor de los bienes y derechos que integren el patrimonio protegido y en proporción, en su caso, al valor de las diferentes aportaciones».

57 Vid., CORDÓN EZQUERRO, «Novedades introducidas en los impuestos sobre la renta de las personas físicas y sobre el patrimonio durante el año 2003», EF, 252, 2004 , pp. 3 a 52. 
ción de su producto para el cumplimiento de su fin. En todo caso, se combina la exención de aportaciones con la de la restitución de los bienes a sus aportantes ${ }^{58}$.

La Ley atiende especialmente a las modificaciones tributarias en tres tributos: a) En el Impuesto sobre la Renta de las Personas Físicas; b) En el Impuesto sobre Sociedades, y c) En el Impuesto sobre Transmisiones Patrimoniales y Actos Jurídicos Documentados.

Por otra parte, tanto la Ley como su Reglamento tendrán carácter preferente sobre lo dispuesto para regular los efectos de la incapacitación en los títulos IX sobre la incapacitación y X sobre la tutela, curatela y guarda de los menores o incapacitados del libro I del Código Civil. Contra esta disposición ha sido interpuesto recurso de inconstitucionalidad promovido por el Parlamento de Cataluña, habiendo sido admitido a trámite por providencia del Tribunal Constitucional del 13 de abril de $2004^{59}$.La fundamentación del recurso se sustenta en la equívoca afirmación de la Exposición de Motivos «la regulación contenida en esta ley se entiende sin perjuicio de las disposiciones que pudieran haberse aprobado en las Comunidades Autónomas con Derecho Civil propio, las cuales tienen aplicación preferente de acuerdo con el artículo 149.1.8 de la Constitución española y los diferentes Estatutos de autonomía, siéndoles de aplicación esta ley con carácter supletorio, conforme a la regla general contenida en el artículo 13.2 del Código Civil».

La esencia del escrito de alegaciones del letrado del Parlamento de Cataluña se sustenta en la incidencia de la regulación estatal en la competencia de la Generalidad de Cataluña en materia de Derecho Civil. En resumen, al utilizar el legislador estatal dos títulos competenciales propios, legislación civil y hacienda general, su conjunción incide en la competencia de la Generalidad ya que, «al regularse la figura del patrimonio protegido en la Ley estatal, y preverse en la misma Ley unas ventajas fiscales que sólo puede reconocer el legislador estatal (...) implica que el legislador catalán puede regular la figura del patrimonio protegido (..) pero no puede regular los beneficios fiscales» ya que, en definitiva, la figura ha quedado vinculada a las ventajas de este tipo ${ }^{60}$.

58 El capítulo III de la Ley está dedicado a las modificaciones en esta materia, ha quedado afectada la determinación de la base liquidable en materia de IRPF, así como el nuevo régimen de las aportaciones por lo que al contribuyente con discapacidad se refiere con un tratamiento fiscal diferente según el aportante sea contribuyente del IRPF o del Impuesto sobre Sociedades.

59 Recurso núm. 1.004/2004 (vid., BOE núm. 102, de 27 de abril de 2004).

60 BOPC núm. 25, 1 de marzo de 2004. 
EL PATRIMONIO PROTEGIDO DE LAS PERSONAS CON DISCAPACIDAD...

\section{REFLEXIONES FINALES SOBRE LAS POLÍTICAS PÚBLICAS NACIONALES: LA POSITIVA MEJORA DE LA LEY 41/2003 POR LA LEY 1/2009 Y LA INCIDENCIA EN EL DERECHO CIVIL DE LA LEY 39/2006}

Si la valoración global de la política de protección patrimonial es favorable, tampoco se pueden obviar ciertos aspectos necesitados de reconsideración. Además de la falta de previsión sobre el régimen de responsabilidad de las deudas del patrimonio, cabe destacar otras deficiencias de carácter más global. En este punto, coincidiendo con el Dictamen que emitió el Consejo Económico y Social sobre esta norma, no cabe duda que un gran número de personas con discapacidad carece de patrimonio suficiente que les permita constituir el protegido por la Ley ${ }^{61}$. Por ello, hay que favorecer «políticas tendentes a proteger y apoyar económicamente al colectivo de personas con discapacidad» si bien los «incentivos fiscales deben ser sólo una pieza e incardinarse de forma coherente dentro de un programa más amplio y general de protección de este colectivo, prestando especial atención a aquellas personas que tengan menor capacidad económica» ${ }^{62}$. Por otra parte y en el entendido de que ciertos aspectos han sido objeto de notable mejora y rectificación por la Ley 1/2009, cabe augurar un incremento en el número de patrimonios que paulatinamente se vayan constituyendo, ya que la reforma ha salvado obstáculos que obstruían la materialización de esta nueva institución.

Adicionalmente, las políticas de la Unión y de los derechos internos de sus miembros, tenían como razón última aprobar un Documento de carácter internacional ${ }^{63}$; en este sentido queremos destacar

${ }^{61}$ En cuanto a la Ley 40/2007, de 4 de diciembre, de medidas en materia de Seguridad Social, su Disposición adicional undécima, sobre el Apoyo a las familias de las personas con discapacidad, impone la siguiente obligación al ejecutivo nacional: «El Gobierno presentará en el Congreso de los Diputados, en el plazo de un año, un estudio que analice globalmente las diferentes posibilidades para las familias de las personas en situación de discapacidad (patrimonio protegido, previsión social complementaria, convenio especial con la Administración de la Seguridad Social y beneficios fiscales) a fin de garantizar una renta suficiente para las personas discapacitadas que, por la naturaleza o gravedad de sus afecciones, no puedan realizar a lo largo de su vida una actividad profesional y se encuentren desprovistas de apoyo familiar».

${ }^{62}$ Op. y loc. cit.

${ }^{63}$ Vid., «Comunicación de la Comisión al Consejo y al Parlamento Europeo. Hacia un instrumento jurídicamente vinculante de las Naciones Unidas para promover y proteger los derechos y la dignidad de las personas, de 26 de marzo de 2003 » y el Dictamen del Comité Económico y Social Europeo sobre la «Comunicación de la Comisión al Consejo, al Parlamento Europeo, al Comité Económico y Social Europeo y al 
que la Convención sobre los Derechos de las personas con discapacidad, suscrita en Nueva York el 13 de diciembre de 2006, ya forma parte del ordenamiento jurídico español habiéndose autorizado su ratificación por Ley Orgánica 1/2008, de 30 de julio. No es ajeno al legislador este Convenio ya que la propia Ley $1 / 2009$, advierte en su Disposición final primera: "Reforma de la legislación reguladora de los procedimientos de modificación de la capacidad de obrar. El Gobierno, en el plazo de seis meses desde la entrada en vigor de esta Ley, remitirá a las Cortes Generales un Proyecto de Ley de reforma de la legislación reguladora de los procedimientos de incapacitación judicial, que pasarán a denominarse procedimientos de modificación de la capacidad de obrar, para su adaptación a las previsiones de la Convención Internacional sobre los Derechos de las Personas con Discapacidad, adoptada por Naciones Unidas el 13 de diciembre de 2006».

En suma tanto las modificaciones operadas sobre la Ley de Propiedad Horizontal como las realizadas en el Código Civil con ocasión de la Ley 41/2003 y la propia creación de esta nueva figura jurídica del «Patrimonio protegido», ponen de manifiesto una cuestión que afecta al ámbito subjetivo de aplicación de las normas antedichas. El legislador convierte en beneficiarios y protagonistas a las personas con discapacidad, estén o no incapacitadas judicialmente. En definitiva y por lo que al Derecho Civil importa, se introduce una categoría hasta ahora vinculada básicamente al Derecho Laboral y de la Seguridad Social como es la discapacidad. Con ello se consigue unificar la llave de cualesquiera medidas protectoras públicas o privadas, que ahora exigen el reconocimiento administrativo previo del grado de discapacidad. Por tanto, en el tratamiento general de la persona, su capacidad jurídica y de obrar, se ha de incluir un concepto procedente de otras ramas del Derecho que no puede ser desconocido y que corre paralelo a la incapacitación, como es la discapacidad; a mayor abundamiento se incorpora otra situación de nuevo corte, como es la dependencia, y el derecho subjetivo de ciudadanía concretado por Ley 39/2006.

Comité de las Regiones. Igualdad de oportunidades para las personas con discapacidad: un plan de acción europeo", de 25 de febrero de 2004, cabe reseñar que son objeto prioritario de políticas presentes y de futuro. 